\title{
Why Biology is Beyond Physical Sciences?
}

\author{
Bhakti Niskama Shanta*, Bhakti Vijnana Muni
}

Sri Chaitanya Saraswat Institute, Govinda Shetty Palya, Konappana Agrahara, Electronic City, Bengaluru, India

\begin{abstract}
In the framework of materialism, the major attention is to find general organizational laws stimulated by physical sciences, ignoring the uniqueness of Life. The main goal of materialism is to reduce consciousness to natural processes, which in turn can be translated into the language of math, physics and chemistry. Following this approach, scientists have made several attempts to deny the living organism of its veracity as an immortal soul, in favor of genes, molecules, atoms and so on. However, advancement in various fields of biology has repeatedly given rise to questions against such a denial and has supplied more and more evidence against the completely misleading ideological imposition that living entities are particular states of matter. In the recent past, however, the realization has arisen that cognitive nature of life at all levels has begun presenting significant challenges to the views of materialism in biology and has created a more receptive environment for the soul hypothesis. Therefore, instead of adjudicating different aprioristic claims, the development of an authentic theory of biology needs both proper scientific knowledge and the appropriate tools of philosophical analysis of life. In a recently published paper the first author of present essay made an attempt to highlight a few relevant developments supporting a sentient view of life in scientific research, which has caused a paradigm shift in our understanding of life and its origin [1]. The present essay highlights the uniqueness of biological systems that offers a considerable challenge to the mainstream materialism in biology and proposes the Vedāntic philosophical view as a viable alternative for development of a biological theory worthy of life.
\end{abstract}

Keywords Aristotle, Consciousness, Darwinism, Determinism, Kant, Species, Evolution, Vedāntic philosophy

\section{Introduction}

Scientists and philosophers were always puzzled by the nature of life, the symptom of being alive. In the modern era, to study an organism, scientists have mainly adopted Descartes' ontological view of the organism as a complex machine [2]. The continued usage of physicalist science to comprehend biological systems is the biggest hurdle in the path of understanding life. The materialistic understanding of reality depends on natural laws, mathematics, determinism, and reductionism. This materialistic science has continually failed to provide a theory for biology [3]. There were several repeated attempts to explain life materially and all of them have repeatedly come full circle, because, physical sciences mostly deal with questions that begin with "what?" and "how?" On the other hand, biological sciences will be incomplete without addressing the functional questions of purpose that begin with "why?"

Biology as the study of life seems to involve much more complex subjects like mind, sentience, consciousness, and subjective experiences like love, affection, anger, happiness, motherhood and so on. However, Darwin and his followers have tried to bring biology under the domain of the

* Corresponding author:

bns@scsiscs.org (Bhakti Niskama Shanta)

Published online at http://journal.sapub.org/als

Copyright (C 2016 Scientific \& Academic Publishing. All Rights Reserved
Newtonian sciences, which are based on certain material laws. Even now there is a general consensus among many biologists that the Darwinian paradigm is a legitimate foundation for the philosophy of biology and human ethics [4]. These views on life deeply affect the thinking of every modern educated person. Therefore, a serious analysis is needed to clearly understand whether the laws that deal with matter can ever address the basics of biology, which are based on concepts. It is not that difficult to realize the uniqueness of certain basic principles of biology that differentiate biological systems from the inanimate world. Material science cannot explain how an artifact/machine can regenerate its lost parts or how it can replicate itself. However, many living organisms effortlessly perform such tasks. The fusion of two gametes (two individual living entities) produces a zygote (a new individual living entity), and symbiogenesis explains that different living entities and their environments are related to each other as an organic whole. Apart from their complexity, even simple biological systems (say, bacteria) have splendid capabilities like sentience, [5] cognition, [6] reproduction, metabolism, replication, regulation, adaptability, growth, hierarchical organization and so on. We do not observe such features in the inanimate world. Can materialistic science ever succeed in making machines imitate many such basic features of life?

The methodology that had been developed on the basis of the materialistic view of reality has continually failed to provide any successful understanding of an 'organic whole' 
- organism. Even the simplest living cells are beyond the grasp of mechanistic tools [7]. Therefore, a careful analysis of the mindless application of materialistic science is necessary to determine whether its basic principles and components are adequate to address the biological realm.

\section{Life and Its Origin are Beyond Reductionism}

Reductionism is the dominant approach practiced among the physicalists and is grounded in the belief that all phenomena are based on material processes that are ultimately reducible to the natural laws. Reductionists claim that theories and laws in different fields of science are nothing but special cases of theories and laws formulated in some other, more basic branch of science, in particular of physical science. Adopting this ideology most biologists are also reductionists and naturally presume that they can explain a biological system in principle as soon as the system is reduced to its smallest components. That is why they are busy in completing the inventory of the components within a biological system and the functions of each one of them. They are under the impression that after accomplishing that task, it would be very easy to explain everything observed at the higher levels of organization. Such approaches have progressed from gross anatomy to microscopy and from organ physiology to cellular physiology. However, all these attempts only establish their inapplicability when it comes to comprehending biological systems using the principles that are basic to the physical sciences [8]. To understand living organisms one may dissect the body of a living organism into muscles, organs, bones, nerves, molecules and atoms. The practitioner of that type of analysis may only gain certain useful new information but those smallest parts will never provide all the answers that are necessary for understanding life as a whole. Even after acquiring a complete catalog of all the molecules of which it is composed, it is not possible to infer structure and function of the biological systems like, cell, liver, heart, lung, brain and so on.

Leaving aside biological systems, reductionism is even unable to explain the nature and teleological function of artifacts. For example, to understand the nature and function of an earthen pot, reductionists may apply appropriate natural laws and also determine what kind of soil the pot is made from, then they can study the structure of that soil under the microscope, and carry on downward through chemistry to the basic molecules, atoms, and elementary particles of which the soil is composed. Such an approach cannot contribute anything towards understanding the properties of a pot as a pot. A sentient subject may use the same pot for many different purposes and thus the purpose of the pot has an external teleological dependence (subject is outside the system) on the sentient subject. Different pots may be made of many different substances like soil, plastic, metals and so on, and yet, they can be used for the same function (say, storing water) by the sentient subject. Therefore, a mindless application of reductionism cannot comprehend the external teleological function of the pot, which is dependent on the sentient subject. Similarly, in a sentient living organism a single chemical structure of a biomolecule can execute many different functions and also one function can be produced by several different chemical structures [9]. Reductionism can at best hunt for correlations and not causal relationships between a structure and a biological function [10]. In a living cell, molecules like proteins can specifically catalyze a chemical reaction or recognize an antigen not only because their amino acids are arranged in a particular way, but also because their three-dimensional structure and function are controlled by the sentient living cell. Without the existence of sentience, as in the case of a dead cell, the same proteins may be present, but they cannot do all those functions that are observed in a sentient cell. The complex functions of the body of a living organism have an internal teleological (subject is inside the system) dependence on the sentient living entity within the body. Being more complex than external teleology, it is impossible for reductionism to grasp the internal teleological functions of different chemical structures present within a sentient living organism.

A recent paper [11] also accepts that, despite a significant progression in reductionism based cell biology, an elementary rationalization of even the simplest subcellular biological processes is missing. In this article, based on the so called notion of theories of "active matter", the authors raised hopes on developing the physical principles of subcellular organization to help establish predictive theories of cell biology. However, the term "active matter" is grossly misleading because matter by its nature is "inactive" and it may apparently be observable as "active" only under the influence of external forces or by the subtle influence of sentient or cognitive principles. Consciousness is a force within the body and only when it is conscious an organism will stand up and perform its usual activities. The moment consciousness leaves, the body collapses. Therefore, by using a reductionism based self organization theory biologists can never discover the natural laws that govern the actual cellular microscopic behaviors of the molecular constituents or the interactions between cytoskeleton filaments.

Aristotle's four aspects of causes [12] will be a good explanation to demolish the great brick wall that we often come up against the attempt to understand living organism from a non-reductionist viewpoint. Let us consider the 'brick wall' example (which is an example for external teleology) in the context of Aristotle's four aspects of causes. If someone asks why a 'brick wall' was built then following a reductionist approach we can only address the two causes from Aristotle's four aspects of causes: (1) the material cause - that out of which 'brick wall' is made and (2) the efficient cause - the natural laws that are important in the art of 'brick wall' construction. However, the simplistic reductionist approach cannot address another two subtle causes: (1) the formal cause - the form or the shape of the 'brick wall' (which was in the mind of the architect) and (2) the final 
cause - the end or the purpose (external teleology) for which the 'brick wall' was built. This is a major limitation of reductionist approach commonly practiced in physical sciences.

The commonly practiced linear causal explanations in physics and chemistry are insufficient to address the network and circular causality of an organic whole. The immensely complex organic whole does not allow reductionism to unravel all the causal relations of a functional dynamic integrated biological phenomenon [13]. Due to a misunderstanding, reductionists falsely believe that causality is a relationship between two chemicals/objects or between a structure and a function. In reality, causality is a relationship between successive events and reductionism cannot establish a unique causal relationship between the structure and the function of a biomolecule in an organism. Therefore, a thorough knowledge of basic molecules, atoms, and elementary particles, cannot explain anything about origin of life, differentiation during ontogeny, subjective experiences and so on. An apparent proof for the same is that, despite their big claims, the overenthusiastic reductionists could not succeed in developing a purely materialistic (Cartesian) theory of biology.

The term biology is of Greek origin meaning the study of life. On the other hand, chemistry is the science of matter, which deals with matter and its properties, structure, composition, behavior, reactions, interactions and the changes it undergoes. The theory of abiogenesis maintains that chemistry made a transition to biology in a primordial soup [14]. To keep the naturalistic 'inanimate molecules to human life' evolution ideology intact, scientists must assemble billions of links to bridge the gap between the inanimate chemicals that existed in the primordial soup and anatomically modern humans. Even though the proponents of a natural origin of life express much optimism for providing their theories, presently there is a detailed compilation of information seriously questioning this doctrine [15]. This reductionistic ideology has always failed to answer two simple questions: (1) what is the minimum number of parts that are essential for a living organism to survive? (2) by what mechanism do these parts get assembled together?

Whether it is between genes and tissues, cells and other parts of the organism, organism and its environment (which includes both living organisms and inanimate objects), a highly intricate and inseparable sentient interaction is the hallmark of biological process at all levels [16]. Due to this specific characteristic of biological systems, we must consider nature, ecosystem, social group, organs of a single organism and so on, as organic wholes. Reductionists should understand that they have a wrong conviction that the organic wholes are mere mechanical and chemical additive sums of their parts. Unlike, mechanical or chemical systems, the parts in a biological system cannot be separated from the system, without destroying it as a working system. Therefore, they can no longer be called parts but are participants or members of a dynamic organic whole. A complete knowledge of the properties of the participating members can never provide a complete knowledge about the dynamic organic whole. Materialists must realize that, to develop proper explanations of mind and consciousness, biology needs a much more sophisticated philosophical foundation than the rather simplistic conceptual framework of the physical sciences.

\section{Darwinian View of Materialism}

The Cartesian view of Organic evolution in Darwinism consists of two dualistic processes, (1) transformation in time and (2) diversification in (ecological and geographic) space. As a result, a purely materialistic view of living organism emerged from Darwinism and it forced scientists to presume that biology is an external superficial amalgamation of (1) functional (physiological activities of living organisms) and (2) historical (evolutionary changes in the dimension of historical time) aspects of living organism.

Assuming that functional aspects of living organisms are under the domain of physical sciences biologists commonly employ the methodology of observation and experimentation to study functional biology. In the due course of time this has also produced a general consensus among the scientists for an extreme reductionistic view that in future based on gene analysis science can understand and control all the functions of living entities including psychological behavior. However, in reality what to talk about psychological behavior, even the simplest physiological functions like muscle contraction cannot be understood by the simplistic reductionistic biochemical explanations such as the interaction between actin and myosin [17]. Biochemical pathways do not precede physiological functions and in reality they both take place at the same time. Therefore, biochemical explanation cannot provide a causal rationalization for the physiological event [18].

On the other hand, to explain biodiversity, evolutionary biologists must confront histories related to extinction and origin of different species. Unlike exact sciences, evolutionists have no way to answer all the relevant questions by experiments and natural laws. Past history of an organism is beyond experimentation, because, scientists cannot show by experiments the extinction and origin of different species. It is impossible to show experimentally the appearance of novel forms in evolution and it is true for both "backward looking view" common descent and "forward looking view" branching. Experimental sciences also cannot establish a unique relationship between natural selection and adaptation. Therefore, the only remaining option is to concoct a fairytale on biogeographic construction and to support that, one must depend on the speculative historical narratives and monotonous methodology of comparison [19]. Without any hint from an authentic source, we cannot know our exact date of birth or our father by an endless guess work followed by trial and error methodology to disprove one guess after another. We may have DNA technologies, but those technologies by themselves cannot tell us on whom we 
should be applying those technologies. If we want to remain arrogant and insist to know everything from our empirical observations then we are forced to rely on endlessly many opinions. We will be forced to apply those DNA technologies on endlessly many individual males all over the world. Most importantly there is no guaranty that by employing a trial and error methodology we will unravel the truth (potential father) even after we succeed in achieving an impossible feat of DNA tests for all the males in the world. Identical twins (www.dnatesting.com/paternity-test-with-id entical-twins) and Human Chimera DNA (www.dnatesting.com/can-my-paternity-test-results-be-wro ng-because-i-have-chimera-dna) are a few such examples where DNA paternity test clearly shows its limitations and especially it will add to more confusion if we have no prior hints. Moreover, DNA technologies cannot do anything if the potential father had already passed away.

Darwin's theory of common descent is based on comparison methodology of Linnaean hierarchy of kinds of organisms. Darwinists come up with many possible historical narratives and try to employ methodology of comparison to come to a conclusion. This methodology is commonly employed in paleontology, embryology, anatomy, physiology and even in molecular biology, where genomics is based on a comparison of base pair sequences. Following the Darwinian methodology of comparison, scientists found that the human genome is incredibly similar to that of chimpanzee [20]. It was observed that $98 \%$ of human genes and many of human proteins (for example, hemoglobin) are identical with chimpanzee, and hence they claim that humans are zoologically nothing but specially evolved apes. However, this comparison methodology cannot explain, despite such close biochemical similarities, why there is such a vast difference in morphology and the nature of consciousnesses among human and apes [21].

In the past, there was a general consensus that due to their rational abilities (man is a rational animal), humans are fundamentally different from other forms of life. However, the superficial methodology of comparison in Darwinism places the human species as a member of the ape family. Most interestingly, this practice of speculating many possible historical narratives and then trying to employ the methodology of comparison to come to a conclusion has created ever widening disagreements between the conclusions of different fields like, paleontology, molecular dating, genealogical data and so on. For example, the method of comparing the morphological characteristics, which was used since the beginning of phylogenetic studies to support different speculations of historical narrative, is now considered insufficient to provide a reliable phylogeny [22]. Yet another speculative methodology of comparison of molecular biology (for example, sequence of base pairs in the genome) is now used to restructure the existing speculative morphological character based phylogeny.

\section{4. 'Natural Selection' or 'Natural Elimination'?}

In an attempt to replace supernatural origin of species in theology with a materialistic proposition, Darwin proposed 'natural selection' as the driving mechanism for evolution. Darwin had taken the idea of 'selection' from animal breeders and plant cultivators, where breeders selected those individual organisms as breeding stock, which had the desired characteristics suiting the breeders' requirements [23]. This 'selection' is a subjective process and also it represents an 'external teleology'. Darwin's 'natural selection' is a disingenuous attempt to replace teleology with a mechanistic principle, because, unlike a breeder, there is no apparent 'self' in the 'environmental conditions' that will perform this subjective task of 'selection'. The word selection itself is misleading, because, 'natural selection' represents a process of elimination and not selection. The whole concept of 'natural selection' is based on the idea that, the least adapted individuals in every generation are eliminated first, while those that are better adapted have a greater chance to survive and reproduce. This elimination process does not represent the process of selection of the best, because, the outcome of an elimination process may be completely different from that of a selection process. In contrast to the elimination process, only the truly best individuals will survive in a selection process. Relatively few individuals in nature will qualify to sustain such a process of selection. In nature, however, there are many aberrant individuals and many organisms have different cumbersome features (for example, tail of the peacock [24]) that contradict this 'selection of best' methodology. Therefore, the selection concept of Darwinian materialism is certainly deceptive and, the appropriate term should be 'natural elimination' and not 'natural selection'.

Under the 'natural selection' framework, it is quite misleading to state that such and such a character had evolved because it was good for the species. The hype of the 'natural selection' mechanism only explains the survival of the fittest and not the arrival of the fittest (production of variation). Therefore, the major question 'how novelty arises?' remains unanswered in the 'natural selection' framework. Till date, how variations relevant to evolution are produced is a major area of controversy in evolutionary biology [25]. The 'natural selection' framework is also confused regarding questions on 'elimination of' and 'elimination for'. Subjective behavior, individual organism, population/group, species, clade, eggs, male gametes, phenotype, replicator/DNA/gene and so on, which should be the object of elimination in 'natural elimination', is also an area of major controversy. A lot of ambiguity can also be found in the usage of the term selection, for example, selection is used for both (1) 'natural elimination' and (2) organisms' choice for food, sex, and other biological needs. 
Therefore, materialism is completely bemused about the 'subject', who performs 'natural selection' and its 'object of selection'. Meanwhile, the framework of speculating many possible historical narratives and then trying to employ methodology of comparison to come to a conclusion, ensures that practicing biologists are the true subjects who perform 'natural selection' and whatever they choose are the objects of 'natural selection'.

\section{Gradualism is a Wanton Imposition of Uniformitarianism from Geology upon Biology}

Darwin's doctrinaire insistence that both species and higher taxa arise through a gradual transformation, reflects that he had a strong belief in gradualism, which he had picked up from Charles Lyell's uniformitarianism in geology [26]. Recent evidence challenges the uniformitarianism assumption based geological column, which is the most commonly used representation for estimating geological time (Cambrian, Ordovician, Silurian, Devonian, Carboniferous, Permian, Triassic, Jurassic, Cretaceous, and Tertiary) [27]. Moreover, till date, the documented fossil record only shows that the occurrences of new species were perfectly adapted and there is no evidence for a frequent production of maladapted species [28]. This offers a direct challenge to Darwin's claim that novel species had appeared progressively from preexisting species by a slow evolutionary process and that at every step organisms retained their adaptation. Molecular biology also offers a significant challenge to this imposition of principles of geology upon biology - 'gradual genome alteration'. Non-Darwinian alterations like transduction, natural-transformation, horizontal (lateral) DNA transfer, fused genomes (symbiogenesis) and so on are examples of a few cases, where genome alteration did not happen by any gradual change and natural selection. Both Darwinian (gradual changes and 'parent-to-progeny hereditary only') and non-Darwinian alterations (rapid changes and transfer of genetic material among non-mating species) do occur frequently in nature, but they always produce only minor changes within species. We cannot find a single case in the scientific literature where either Darwinian or non-Darwinian alterations successfully led to the appearance of any new species. Kuhn emphasized this fact in his article 'Dissecting Darwinism':

"In all fairness, there is convincing evidence, that is widely acknowledged, that random mutation and natural adaptation (Darwinian evolution) does occur within species, leading to minor changes in areas such as beak size, skin pigmentation, or antibiotic resistance. Some of these changes involve a simple biologic survival advantage for a population, without a mutation in DNA. Others might be influenced by a single deletion or insertion within the DNA strand. However, the modern evolution data do not convincingly support a transition from a fish to an amphibian, which would require a massive amount of new enzymes, protein systems, organ systems, chromosomes, and formation of new strands of specifically coding DNA. Even with thousands of billions of generations, experience shows that new complex biological features that require multiple mutations to confer a benefit do not arise by natural selection and random mutation. New genes are difficult to evolve. The bacteria do not form into other species." [29]

\section{Species and Speciation Problems}

The principal unit of evolution, "species" is one of the most important concepts in evolutionary biology and no meaningful conclusions can be achieved without understanding, what a species is. A lot of dissension can be observed in evolutionary biology, because, different scientists use the same term "species" to describe completely different phenomena. We can also often observe in the literature a lot of discord and great confusion about biological meaning of "species" and 'origin of species'. Variety is the spice of life and it is very difficult to develop any proper "species" concept on the basis of a flabby comparative analysis. In some cases, even among individual members of the same population such significant differences are observed by sex, age, season, minor genetic variation and so on, that some comparative analysts may recognize them as different species. On the other hand, there are many groups of organisms coexisting in nature, which are extremely alike with no virtually noticeable distinct characteristics, yet they do not interbreed. If a definition of species is employed for such organisms, on the basis of reproductive isolation, it will not be valid for asexually reproducing organisms. Asexual organisms do not reproduce with other species and thus following a species definition based on reproductive isolation we have to categorize every individual asexual organism as different species. Sometime, an individual from a species may hybridize with another species. Moreover, a peculiar reproductive barrier may exist among reproductive community, where it can be observed that even though coexisting at the same place, members of same species do not normally interbreed with each other. Therefore, certain populations may attain reproductive isolation with minimal or no morphological difference, while on the other hand, some other populations may gain noticeably different morphologies without any reproductive isolation [30]. It is rather a weird methodology, because, a morphology based species diagnosis is applied to asexual organisms [31] while on the other hand, reproductive barrier based species diagnosis is applied to sexually producing organism [32]. Also, from the literature survey it appears that species cataloguing is dependent on the diagnostic choice of the individual subject - the researcher. Different researchers have employed several species definitions based on differences observed in geographic races, colonization, number of sets of chromosomes in the cells, morphological characters, phenotypic characters, niche specializations, 
subjective behavior and so on. Therefore, at present, for species identification, biologists do not have any established scientific method.

The adaptationist explanations on evolution of population with a change in the environment, have not yet addressed biodiversity - the branching off of a species from its parent species. Sometimes, two populations of the same species may undergo spatial isolation for various reasons and that may lead to the development of sterility barriers or behavioral incompatibilities, causing a reproductive isolation between those two populations. However, a speculation on these accidental, adaption or survival based geographic explanations of the proliferation of life (microevolution) in the past, explains nothing about how one living form transformed into another (macroevolution) over a period of time. Several confusing and conflicting claims on this can be observed among evolutionists, because in different evolutionary studies evolutionists analyze the results of past evolutionary processes and due to the lack of any exact predictive methodology, they are forced to reach their conclusions by guess work on often varying narrations of historical sequences. Moreover, the hype of advanced genetic research is also inept at explaining the exact sequence of genetic processes that leads to speciation [33]. It is now more and more evident that speciation of different types of organisms essentially needs different genetic regulatory networks. Jacob and Monod discovered that different organisms have different kinds of genes - structural and regulatory [34]. How random mutations can produce those different novel genetic networks and how those novelties in an individual were transformed to the population, are the important unanswered questions addressing multiplication of species. A cognitive level philosophical explanation is necessary to address how and why new species arise and an adaptationist approach in genetics is inapt to address these questions.

\section{Scientifically Tenuous "Chanciness" is the Foundation of Darwinism}

To support their ever changing historical narratives and necessary variations, evolutionists are also forced to invoke the role of "chance". However, when "chance" is invoked anything and everything can be claimed and supported by the argument of "chance". That is why invoking chance in any explanation is unscientific, as even realized by some of Darwin's contemporaries, for example the geologist Adam Sedgwick. Moreover, mathematical calculations also establish that biology is beyond the simplistic explanation of "Chanciness" [35]. However, without chanciness Darwinism will not survive and that is the reason why till date the evolutionary biologists are forced to invoke chance to provide the historical narratives of evolution. To avoid the role of sentience, biologists were invoking "chance" and denying that genetic variation is a response to the adaptive needs of an organism. This is the reason behind their claim that there is no inheritance of acquired characteristics, which also instigated a rather rigid imposition of central dogma of molecular biology that information can be transferred only from nucleic acids to proteins and not from proteins to nucleic acids [36]. However, all these dogmas are now completely disproven and 21 st century biology thoroughly accepts the organism as a self modifying being [16].

\section{Can Population Thinking Bring Biology within the Domain of Exact Sciences?}

Darwin introduced the idea of population thinking almost as if by necessity to accommodate the Newtonian framework of exact sciences based on natural laws. The monistic outlook in physical sciences believes that the world is made of different classes, with the members of each class being identical, and with the apparent differences being inadvertent and therefore extraneous. We can clearly notice this typological mindset of physical scientists, where it is presumed that fundamental entities of matter like, the nuclear particles and the chemical elements are constant and sharply delimited against each other. However, in the biological realm, every individual (even identical twins are unique entities [37]) is unique. The living world consists of social groups and in contrast to Darwin's view of competition, organisms live in a subjective cooperative environment. Within those social groups, the choice of food and surroundings, exhibition of ethics and pride, and so on, vary from individual to individual. Hence, the attempts to represent biological systems abstractly by a mathematical or statistical mean value of a population is only a misrepresentation. The generalized laws of materialism do not bother about individuality in the inanimate world, but, such a consideration is a must in the biological realm.

\section{Internal and External Teleology}

In the past, many naturalists were convinced that living organism poses a certain immanent force that does not exist in inanimate nature. They provided solid arguments to distinguish the living organisms from the inanimate objects. However, many of those views are also influenced by the mechanistic outlook of reality. Metaphorically some naturalists believed that, as an invisible gravitational force controls the motion of planets and stars, similarly, the movements and functions of a living organism are controlled by an invisible force (Lebenskraft or vis vitalis) [38]. Naturalists believing such a view are called vitalists and their metaphorical dependency on mechanical explanation of reality is the real cause of the downfall of vitalism [39]. Scientists can explain the physics of motion of inanimate objects by laws of physics. However, a living organism has a 'conscious self', which is endowed with 'freewill' or 'self-determination'. It is very easy to understand the 
distinction between living (animate) objects and non-living (inanimate) objects through a simple observation of their movements. The trajectory of motion of an inanimate object like a satellite can be predicted in terms of the laws of mechanics. However, the motion of an animate object like a bird cannot be understood with the same principle. This is because, an animate object is self guided. Newton's first law of motion is applicable to a marble (inanimate object), but it cannot be applied to a tortoise (animate object). The motion of inanimate objects is determined by an external force. We need an external force to move a marble at rest. On the other hand, animate objects display a self driven spontaneous movement, which is indeterminable from the natural laws. A tortoise at rest can decide when it wants to move and no law in physics can determine that decision. Therefore, it is necessary to investigate, whether animated systems are based on certain additional principles that are beyond the domain of natural laws of the physics and there is a genuine need for a restructuring of the conceptual science of 'animated systems' - a non-materialistic spiritual biology.

There is nothing in the conceptual repertory of Cartesian science that would allow scientists to distinguish between the external goal-directed processes of the inanimate world and the internal goal-directed processes in living organisms. Despite the fact that, all materialistic theories are only valid for inanimate objects, most biologists have grossly ignored the thoughtful philosophy on "teleology" by Aristotle and Kant. In the world of inanimate objects, we find that different processes persist towards an endpoint in an automatic way, regulated by external forces or natural laws. Liquid flows or inanimate objects fall from upwards to downwards, following the law of gravity; heat flows from a body of higher temperature to a body of lower temperature, following the law of thermodynamics. Using knowledge of the natural laws that are apparently governing the inanimate world, a designer may design an artifact (machine). However, all such inanimate systems are ontologically different from that of biological systems. According to Aristotle the movements of inanimate objects are caused "by necessity" [40]. Therefore, they may have an endpoint, but, the goal of such inanimate systems is determined externally by the natural laws or the designer. The question what for? (wozu?), can only be addressed from an external point of view for such inanimate systems. However, systems governed by natural laws are something entirely different from animated objects - living organisms, where inner intentions and purposive acts of the individual living entity must be invoked to illustrate the teleological processes. Unlike the inanimate systems, inner purpose, intention, psychology and consciousness are unique for each living individual even within the same species. Therefore, an externally driven causal explanation of physical science is insufficient to address the living nature.

The ideological imposition of Newtonian mechanistic science on biological systems has completely ignored the overtly noticeable goal-oriented or teleological activities (self-determination, self-formation, self-preservation, self-reproduction, self-restitution and so on) of living organisms, which make them distinct from insentient mechanical and chemical systems. The principle of "internal teleology", which deals with the immanent processes in a biological system that leads to a definite end or goal, places biology in a distinct category from that of physics and chemistry. Aristotle proposed causa finalis as a fourth cause to explicate the development of the fertilized egg to the adult of a given species. German philosopher Immanuel Kant specifically emphasized that Newtonian natural laws cannot explain the teleological ability (Zweckmässigkeit) [41] of the biological world.

Despite all those convincing views, a dominant materialistic outlook of reality in science did not allow the establishment of biology as an autonomous science. The presumed materialistic mindset does not allow invoking "teleology", because, by doing that it may provide a space for theological philosophies in modern science. However, the scientific method itself is not applicable only to the metaphysics of materialism. The goal of real science is to follow the evidence wherever it may lead.

\section{Code Delusion in Biology}

In an artifact like a computer, coded or prearranged information controls the processes leading it toward a goal desired by the designer. To provide a strict deterministic explanation to the teleological processes in living organisms, biologists have also followed the mindset of physicalists and invoked the concept of code. This borrowing of the anthropomorphic term 'code' from informatics is the reason behind the metaphorical postulation that the organism is an information processing machine. The concepts of 'genetic code', 'neuronal code' and so on are outcomes of this mentality. To accommodate the deterministic mindset of physical sciences, Darwinists presume that living organisms are subject to dual causation. They think that living organisms are controlled by (1) natural laws and (2) genetic and neural codes. The central theme of this concept is that, each particular code within different living organisms is the result of natural selection continually corrected by the selective value of the achieved endpoint. The one-to-one relation between genotype and phenotype, and consequent claim that 'genome is a code that directs development' is certainly incorrect because, the development of phenotype involves many immanent sentient principles and environmental factors [42]. The unrecognized role of consciousness in transfer of information/instruction within living organisms inevitably exposes the most misleading description of a code concept in biology. Despite several tedious efforts, the genetic and molecular basis of such innate codes could not be found till date [43]. This indicates that, the so called stored historically acquired information in a biological system is still inaccessible to materialistic science. In another paper the first author of the present essay also discussed the demise of the 'neural code' concept [1].

The demise of strict genetic determinism - 'central 
dogma', [44] certainly establishes that, life does not follow the mechanistic processes that we observe in computers. Moreover, it has been reported that enucleated cells continue to survive and display a regulated control of their biological processes for up to three months $[45,46]$. Therefore, the notion that total instructions for an organism's behaviors and functions are laid down in the DNA of the genotype is certainly incorrect. Purposive behavior that is noticeably goal directed is ubiquitous in all living organisms and these teleological activities of living entities offer a significant challenge to the deterministic genetic code concept. Even the simplest of living organisms like bacteria display learning and sentient reflexes that defy the strict deterministic views of the genetic code [16]. In developmental biology, each stage in ontogeny, together with surrounding environment, necessarily require another much more sophisticated wholistic control system, apart from the DNA based code concept.

The equivalence between the code of the information theorists and the genetic code of the biologists seems to be exceedingly superficial. There are no genomic or other molecular units for life [47]. The genetic substance itself is a dynamic structure and functions as a co-participating member in an organic whole. Till date, Darwinists could not show the materialistic origin of even goal directed adaptedness (Kant's Zweckmässigkeit) in living organisms. Several organic processes and activities are clearly teleological and biologists could not reduce them to physicochemical causes, because such goals of living organisms are not found in any innate codes inside the body of a living organism. The special internal teleological (Naturzweck) aspects in biology are not directly observed in inanimate objects and thus constitute the demise of the mere physicochemical grasp of living nature. We need to understand biology based on cognitive analysis and not mere molecular depiction of the constituents of the body of the living organisms. In biology, there is no activity, movement, or behavior of an organism that is not influenced by its sentience [48]. The various activities of chemical structures and the messages from the genome function simultaneously and in harmony only when the organism is alive or sentient. Sentience is the absolute feature distinguishing the inanimate and the living world. Therefore, the theory formation in both physiology and transfer of information/instruction must be based exclusively on cognitive science. Since a long time naturalists were aware of this fundamental difference, but unfortunately, due to a dominant influence of the materialistic outlook of reality it was not in the forefront of modern science.

\section{Evolution from Mindless Physics to Mind Dependent Physics}

Many have the presumed notion, especially in the field of biology that matter is a well understood concept. However, to avoid unnecessary confusions, it is important for biologists to deeply understand the concept of matter before they could claim things like 'life is a chance combination of matter'. The atomic concept in physics has given way to quantum mechanical models, where the subatomic particles cannot be held to be localized in space. They are spread out in a form approximated by some probability density function that gives the likelihood of being found at a given location when a measurement by an observer supposedly collapses the wave function to a particular location. Quantum mechanics (QM) introduces non-locality [49] to the concept of matter. Furthermore, the uncertainty principle gives the limits of knowability about something as far as precise location and momentum is concerned [50]. The observed results depend upon the choice of experiment (for example the results of the Compton's scattering experiment was modelled by assuming a particle nature of light (photon) and double slit experiment is explained by interpreting a wave nature of light). Quantum field theory further treats the particles as quanta of quantum mechanical field. Quantum field theory was proposed and developed by many pioneers like Paul Dirac, Dyson, Feynman, Julian Schwinger and others [51]. We cannot conceive of merely a one particle system or even a many particle system in nature. The elementary particles are created and annihilated by processes called pair production and pair annihilation. In the relativistic QM we are forced to consider an infinite number of electrons and positrons in vacuum. In the quantum field theory the particles of nature are considered as quanta of relativistic quantum fields [52].

Many experiments in $\mathrm{QM}$ also disprove materialism whose loudest name is naïve realism. These include the experiments involving double slit, EPR pairs, Stern-Gerlach experiment and the more recent experiments of Zeilinger's team. As Zeilinger's team state:

"Here we show by both theory and experiment that a broad and rather reasonable class of such non-local realistic theories is incompatible with experimentally observable quantum correlations. ... Our result suggests that giving up the concept of locality is not sufficient to be consistent with quantum experiments, unless certain intuitive features of realism are abandoned." [53]

The Copenhagen interpretation of $\mathrm{QM}$ given by its founders Bohr and Heisenberg is still the most important idea of QM. The Copenhagen Interpretation asserts that the wave function represents our knowledge of the electron, and not the electron itself [54]. Zeilinger has also shown through his experiments that multiple particles can be entangled. Using quantum teleportation the characteristics of one particle can be transferred to another. Thus Zeilinger says:

"Why are you so realistic? If you analyze your fundamental notions you might conclude that these things are more counterintuitive than you think ... Why do you want a hidden reality that exists independent of the observation?" [55]

In this way $\mathrm{QM}$ is a progress from observer independent classical physics to an observer dependent description of reality, where it has shown us that we are not directly dealing with the Science of Object but we are dealing with the 
science of knowledge of the object. Hence, physics has realized that matter does not have an independent existence apart from consciousness.

Different aspects of the inquiry about consciousness have centered around three main categories called (i) Particulate Philosophies, (ii) Process Philosophies and (iii) Spiritual Concepts in different World Religions. Modern science has pushed a particulate conception of life and consciousness under the broad category of materialism. However, as we discussed above the advent of Quantum Physics has deduced that the particulate conceptions in classical sense do not exist and they are just approximations of classical thinking. These have further ramifications for gene based concepts of life processes, which were already shown to be limited ideas or approximations when the unknown transfers (which deviate from central dogma in molecular biology) were shown to be ubiquitous in all living organisms [16].

\section{Consciousness is Beyond the Reach of Physical Sciences}

Based on empirical evidence, the first author of the present essay proposed the ubiquity of consciousness in all life forms starting from bacteria to human being [1]. In the same article it is also explained that the individual cells in the multicellular organisms also exhibit individual cognitive behavior. Physical sciences leave no room for the subjective aspect of consciousness in its attempt to understand living organism in terms of relationships among forces, atoms, and molecules. The mechanistic approach in physical sciences created the duality between the experience and the experiencer - "easy problems" and the "hard problem" of consciousness [56]. David Chalmers first highlighted that the problems in the study of consciousness can be divided into two separate types: the "easy problems" and the "hard problem" of consciousness [57].

One should not be misled by the term "easy problems" of consciousness because the problems under this category are very far from having been solved. What Chalmers meant by the "easy problems" of consciousness is that, for the problems in this category, scientists can imagine some mechanism to explain the phenomena. For example, scientists may try to explain the injury suffered by the body of an organism as the cause of the pain experienced by that organism. To find further details, scientists may explain that pain reception in an organism happens through a certain type of nerve fibers. In this way scientists try to construct some type of mechanistic explanation to explain the organism's subjective experiences, like hearing, vision, smelling, memory, and so on. Because this type of approach is in line with the classical methods of scientific observation and experimentation, they call this category "easy problems." The studies in the field of 'cognitive science' and 'neuroscience' are only trying to address these 'easy problems'. Following this mechanistic approach, [58] Crick [59] and Koch [60] proposed neurobiological view of consciousness to address the memory (storage of information) and binding of information contents (integration of information) in the brain. Till date we do not know how this storage and binding might be achieved [61] and even if we unravel this mystery it cannot answer 'why we experience things?' Edelman's Neural Darwinism model [62] also fails to address the cause of conscious experiences. Jackendoff's computational approach [63] in his 'intermediate level' theory is also inapt to address conscious experiences. In recent literature we can find some extreme speculation and deceptive claims that like human being, genetic programming in computers can also produce new and significant things including new scientific discoveries [64]. However, honest scientific critiques debunk all such naive claims:

"the fitness directly incorporates laws of physics. Thus, a major claim that "[w]ithout any prior knowledge about physics ... the algorithm discovered Hamiltonians, Lagrangians and other laws" appears to be false." [65]

All these mechanistic approaches simply presume that they can easily address 'conscious experiences' once functions like accessibility, reportability and so on are explained. However, merely knowing the mechanistic explanations, like neurophysiological processes, functions, states, and operations that are necessary for the sense perception cannot fully elucidate the questions: "how sensations acquire characteristics, such as colors and tastes?" and "how an organism develops a sense of self?" Mechanistic explanations can never address the much more complex conscious realm-selfhood. Because of this, scientists consider this problem under the category of "hard problem" in connection to consciousness. Thomas Nagel describes the difficulty:

"It isn't easy to absorb the fact that I am contained in the world at all. It seems outlandish that the centerless universe, in all its spatiotemporal immensity, should have produced me, of all people - and produced me by producing TN [i.e., Thomas Nagel]. There was no such thing as me for ages, but with the formation of a particular physical organism at a particular place and time, suddenly there is me, for as long as the organism survives. In the objective flow of the cosmos this subjectively (to me!) stupendous event produces hardly a ripple. How can the existence of one member of the species have this remarkable consequence?" [66]

As none of the old methods are found to be useful to solve the mysteries of consciousness, in recent time different researchers are showing optimism on new speculations in nonlinear dynamics, non-algorithmic processing, [67] future discoveries in neurophysiology, QM [68] (the QM approaches to consciousness simply presume the existence of consciousness and utilize it in the elucidation of quantum processes) and so on. However, all these speculative suggestions possibly will explain the physical role that consciousness may play but most importantly all of these approaches are also suffering from the same limitation (why should these processes give rise to experience) that outmoded the old methods. Thus it indicates that any attempt towards a purely physical explanation of consciousness will 
always suffer from the same criticism. The physicalistic approaches (which only try to address structure and function) in the studies on consciousness cannot overcome "why" and "how" questions [69].

Semiotics makes a clear distinction between life and non-life in terms of sign processes. Saussure offered a dyadic model of sign as composed of a signifier, which is the form that the sign takes and the signified or the concept it represents [70]. Pierce on the other hand offered a triadic model of sign, [71] which includes the aspects of representamen (the form that the sign takes), an interpretant (the sense made of the sign) and an object to which the sign refers.

In semiotics, there is recognition of the concepts of cooperation as well as cognitive science. Furthermore, here there is the recognition that we lack tools to address biology. For example Robert Rosen explained, "The "basic reason why biology is hard' is 'because we are fundamentally ill equipped"" [72]. Elsasser recognized that one of the main difference between life and nonlife was creativity [73]. Similar to the problem of origin of life, semiotics also grapples with the question that how these sign systems (biology) arose. In spite of DNA based understanding that was pushed in the 20th century, semioticians like Sebeok have claimed that the definition of life coincides with the definition of semiosis [74]. In Peirce's words, omne symbolum de symbolo or every semiosis comes from semiosis [75]. This is similar to the idea of Rudolph Virchow that every cell comes from cell or omnis cellula e cellula [76]. Similarly, Vedāntic paradigm proposes scientifically verifiable axiomatic fact 'life comes from life', [1] which was also recognized by Pasteur (Omne vivum ex vivo biogenesis) in his experimental work. Semiotics recognizes that life processes are learning and knowledge gaining processes. Uexküll is regarded by many as the father of zoosemiotics [77]. For Uexküll, epistemological problems in biology were very important considerations. He contributed the idea of umwelt. Uexküll tried to address the observed phenomenon that the living beings have subjective perception of their environment as well as their inner perceptual world, which determines their behavior. The concept of umwelt accepts the truth of the relation between the perceptual as well as the operational world of living organisms. The umwelt is governed by the meaning it has for the subject [78]. It is inferred that the action of signs are of prime importance in determining all aspects of life processes. The living entity constantly interprets its internal conditions as well as the environment and makes choices by which it can sentiently respond to stimuli. Uexküll also defined a term called the semeiotic niche [79]. Grinnell defined the niche as the totality of places where organisms of a given species might live [80]. On the other hand, niche is also a functional term, which means a description of the ecological role of the species and its way of life [81]. Emmeche explains:

"In brief, cognitive science found itself saddled with the problem of how to account for the aboutness aspect of consciousness - conscious processes (like the processing of symbols and similar intrinsically intentional phenomena) are about something, and usually refer to something other than itself." [82]

Emmeche further explains that the standard model of observation for natural science involves a presupposition that a clear distinction exists between a subjective observer and the object observed. This at once breaks down in the case of consciousness. Consciousness is at once both observer and observed. The field of semiotics considers its approach to consciousness as a fully valid method [82]. In this way, it can be inferred that the sign processes and sign actions are real and genuine processes as there is communicative and meaningful paradigm that is intrinsic to cognitive phenomenon. There are qualitative aspects, which are foundational that relate to sign actions, in relation to cognitive processes and are necessary to form an alternative and more comprehensive framework. In this approach we have to study how the sign process develops between an individual subject, other subjects, the external world and forms. All these aspects form an inseparable wholistic unity in terms of semiotic relations.

Philosophers have always understood these problems which science is now being forced to acknowledge in different ways. Immanuel Kant very emphatically wrote, "There will never be a Newton for the blade of grass." [83] The subjective half of consciousness cannot be neglected at all because it requires consciousness to be conscious of itself. Great philosophers like Anaxagorous, Socrates and Plato considered thought/thinking and the rational concept as foundational realities. This must be so (as discussed above) even in modern thought due to the conclusions of both the theoretical and experimental sciences combined together.

The life principle cannot be understood properly without overcoming the subject-object duality. There cannot be any content-part (object of consciousness) without a subject-part (conscious self) and vice versa. We should not deny the conscious phenomenon (our mental lives) just because it is not possible to externally verify it. Subjective experiences cannot be observed directly by some experiments, but all of us experience them. Consciousness has to be taken as fundamental and it cannot be explained in terms of anything simpler. To accommodate the non-material aspect of conscious realm we have to include "soul hypothesis" within the scientific studies.

\section{A Brief Introduction to Vedāntic View on Consciousness (cetan $\bar{a})$, Species (yonih) and Evolution}

Aristotle explained an empirical basis to arrive at the concept of soul as the first principle of living things in de Anima [84]. It is a very useful treatise and the renowned German philosopher G.W.F. Hegel has praised it as "by far the most admirable, perhaps even the sole, work of philosophical value on this topic" [85]. We should not ignore the study of "soul" just because it is unobservable by empirical means. The idea of soul should be deduced from an 
understanding of concepts and necessity. Aristotle was convinced that there are living things in nature that are quite apart from non-living objects like rock. He explained that an acquaintance with the thought of soul makes a great contribution to the truth of everything and especially to the study of nature [84]. In de Anima, Aristotle talked about five psychic powers of the soul: 1. Nutritive, 2. Appetitive, 3 . Sensory, 4. Locomotive and 5. Mind/Power of thinking [84]. Every living entity possesses "Nutritive power (nourishment, reproduction, and growth)" and it enables the living entity to survive or continue in existence. Except plants all other living entities have the next three psychic powers: Appetitive, Sensory and Locomotive. Aristotle places 'thinking ability' as the highest psychic power of the soul and this ability is only with human beings. Based on this psychic powers Aristotle made three separate division of the soul: (1) Nutritive soul (plants), (2) Sensitive soul (all animals; Aristotle placed Appetitive, Sensory and Locomotive psychic power in a single category of soul) and (3) Rational soul (human beings). According to Aristotle the concept of life in a potential form becomes actualized by necessity. Thus, life is the stage or process of the development of the soul by necessity. It is self determined - what comes out of the potential is already within the potential and is nothing new. The purpose or the final cause is an integral and inseparable limb of the principle of Causality which modern science neglects.

According to Sańkhya philosophy, there are two types of bodies: (1) Sthüla-deha: The gross body-the body that can be sensed by hearing, smelling, tasting, seeing, and touching, and (2) Süks ma-deha: The subtle body (within the gross body) - mind (manasāa), intelligence (buddhi) and false ego (ahańkāra). In general, in western philosophy they seem to assume soul (ätman) and subtle body (sükș ma-deha) as one and the same thing - psyche. On the other hand, according to Sańkhya philosophy the subtle body (sūkș ma-deha: mind (manasāa), intelligence (buddhi) and false ego (ahańkāra)) acts as a connecting link between soul (ätman) and gross body (sthüla-deha). The subtle body (sükș ma-deha) is the major difference between western philosophy and Vedāntic view. Therefore, unlike Aristotle, in Vedāntic philosophy every soul has the same psychic power in the potential form, but due to its conditioned state of consciousness it cannot express it. Different men can go at different speeds by using different vehicles: bicycle, high speed car, airplane and so on. It is improper to classify men based on those speeds, because the speed differences are not coming from men. The speed difference is due to the different abilities that are available in those vehicles. Similarly, according to Vedāntic philosophy different souls may be present in different bodies and due to the limitations as result of conditioning of those bodies the souls (despite having same abilities in potential form) cannot manifest their full potentials.

The psychic power based classification of "Soul" by Aristotle is similar to the classification of consciousness in Vedāntic philosophy. In Vedāntic view there are five different levels of consciousness: (1) ācchādita: Covered consciousness manifested in living entities like trees, (2) sarikucita: Shrunken consciousness manifested in animals (mainly focused on immediate biological needs: eating, sleeping, mating and defending), (3) mukulita: The beginning of human consciousness (without a sense of absolute truth), (4) vikachita: When men start developing a sense of absolute truth and (5) pürna-vikachita: When a person had developed pure love towards the absolute truth [86]. In Vedāntic concept different species represent different developmental stages of consciousness. Unlike modern dualistic western philosophy, in the Vedāntic view, the mind and body of the living entity forms an inseparable unity. We can take the analogy of coin. A coin has two distinct sides - the heads and the tails but still they form an inseparable unity or an identity in difference. When we break this unity of the living entity, the resultant product becomes lifeless. To study life we have to also study death. At the time of death consciousness is lost and that is called the death of living entity.

Consciousness always means consciousness of something. The living entity can be conscious of objects in the environment and at the same time when it becomes the object of its own consciousness, it is called self consciousness. Trees, plants, creepers and grass are examples of living entities having covered consciousness ( $\bar{a} c c h \bar{a} d i t a)$. These living entities have almost no sense of their own conscious existence, yet their identity as living entities can be inferred from the six transformations of life as observed in living entities: (1) birth, (2) sustenance, (3) growth, (4) maturity, (5) declination and (6) death. According to Manu-samitä the trees have feelings of pain and pleasure similar to ours and their souls are not of a lower standard [87]. However, their consciousness is not yet developed to the extent of animals and the still higher category of human beings. Terewavas has argued that plants display sentient qualities like sensory perception, information processing, learning, memory, choice, foresight and predictive capacity [88].

Animals, birds, crawling and creeping entities like reptiles, snakes, insects and fishes living in water are all examples of different degrees of shrunken consciousness (sarikucita). These organisms have a more developed sense of their conscious existence. They distinctly display the characteristics towards satisfying their immediate biological needs like eating, sleep, fear, willful migration and travel, fighting with others due to a sense of self, display of anger when they see injustice, and so on. But they have no sense of self inquiry (athāto brahma jijñāsāa - Vedānta-sūtra 1.1.1) and they are fully engrossed only in immediate existence. Sometimes it is observed in monkeys that they have a small sense of learning or gaining practical knowledge and realization within their restless activities [89]. In certain situations they also display feelings about the consequences to a certain degree and even we can find symptoms of gratefulness in them [90]. Sometimes animals also possess a sense of knowledge about different substances [91, 92]. It has also been documented in recent times that sometimes even wild animals like lions apart from monkeys, dogs, and 
other animals develop some sense of empathy when they come in human contact [93]. de Waal, a renowned biologist and primatologist with expertise in studies of behavior and social intelligence of primates explains:

"There is increasing evidence, mostly in mammals but also in birds that animals are sensitive to the emotions of others and react to distress in others by attempts to ameliorate their situation or rescue them. There are experiments showing the same, so these videos are to be taken seriously as illustrations of this tendency." [94]

Animals do not normally enquire after real self (beyond body) and God. Therefore, their consciousness is categorized as shrunken consciousness (sarikucita). As mentioned earlier, the consciousness in human stage is very broad and is categorized in three stages. The human stage covers different aesthetic categories like morality and ethics. The human stage can be moral-less, moral, moral with a developing sense of absolute truth, working for the absolute truth and those with a developed dedication with developed love towards the absolute truth. The moral-less and moral without a sense of absolute truth are budding consciousness (mukulita). Moral with a developing sense of absolute truth and those working for the absolute truth are the stage of blossoming consciousness (vikachita). Those humans who have developed dedication with developed love towards the absolute truth are called completely developed stage of consciousness (pürṇa-vikachita).

The pañca-kos'a concept has been elaborated in the Brahmānanda-vallì of Taittirīya Upanișad, where different living entities are categorized into five inter penetrating concepts: (1) anna-maya, (2) prāna-maya, (3) mano-maya (jñāna-maya), (4) vijñāna-maya and (5) ānanda-maya. The anna-maya stage is the feeding stage or the stage of food consciousness and it is implied by the Sanskrit term anna, which means food. All living entities subsist on food and therefore anna-maya stage is common to all life forms. This was also understood by Aristotle, when he explained that the nutritive stage is common to all life [84]. We can observe that every living entity is conscious of food in the beginning stages of the development of consciousness. They are satisfied by getting palatable and nice food. In this stage of consciousness the goal of life is to eat sumptuously.

After the anna-maya layer, comes the prāna-maya layer of consciousness. The living entity wants to preserve his consciousness of being alive. The living entity becomes conscious of protecting itself from being attacked or destroyed. In this way the living entity feels some happiness in being alive. Therefore, prāna-maya stage can be seen as the consciousness of one's own existence and is the immediacy of the living symptoms, which is found in the vitality of all living organisms.

After the pranna-maya layer comes the mano-maya layer of consciousness. Plants, animals and humans have the potential for self-recognition to different degrees. All living entities contain in degrees some mental or cognitive quality and thus mano-maya stage is the mental stage. But the human stage is more advanced than plants and animals. The characteristic of mano-maya layer is that it produces mental speculations among human beings as well as in other species leading to different social and cultural identities. The whole of materialistic civilization is in this way primarily based on these three stages known as anna-maya, prāṇa-maya and mano-maya. The main goal of the civilized people is economic development, self-defense against annihilation, and further the mental speculations and the philosophical approach towards realizing the material values of life.

After the mano-maya layer of consciousness, there is the vijñana-maya stage of consciousness. The pure soul lives in the vijñanna-maya stage. By reaching the rational and the intellectual phase of life when a person understands that he is a spiritual soul (atman), he becomes situated in the vijñana-maya stage. Aristotle also explained that, "Man is a rational animal". Human life is specifically meant for self-inquiry and fulfilment by spiritual development. It is the stage when consciousness can withdraw from all mental speculations and does not identify himself with the material field or the body and becomes engaged in the higher necessities of the spiritual culture.

After the vijñanna-maya layer there is yet another higher layer called the annanda-maya stage. The living entity or the soul is meant to gradually evolve its consciousness up to the highest state called annanda-maya stage. In this stage one attains perfect happiness and fulfilment by fully engaging oneself in loving devotional services of the Supreme Absolute. Thus, depending upon the development of consciousness or its degradation, the soul (ätman) has the potential to go down in different stages of material consciousness like plants, insects, animals or human being, or become situated in its true unmixed spiritual identity as a serving member of the Absolute plane.

These five stages are hierarchical, interpenetrating and nested. All living entities, from the simplest on up, are covered by this enjoying tendency or the tendency to be fulfilled. But due to a lack of proper knowledge to attain lasting fulfilment (ananda) they are suffering in temporal material plane of pain (dukha) and pleasure (sukha). However, only a perfectly self-realized sage knows the proper process for establishing oneself in the plane of lasting fulfilment (ānanda). This is the stage of fulfilment (ānanda) and thereby the soul (ätman) can contribute dedicated service to the Supreme Absolute under the guidance of proper authoritative source. The dedicated stage is the stage of unalloyed happiness and is characterized by grades and various themes of ecstasy. This gradation presented in Upanișads indicates the different stages of material bondage, release and finally the progress towards lasting and completely unmixed dedication to the Supreme Absolute.

In Vedāntic view all the aforementioned stages of consciousness can be broadly categorized as exploitation (bhogā), renunciation (tyāga) and dedication (bhakti) [95]. The two lower stages of consciousness, covered (ācchādita) and shrunken (sarikucita) stages come under exploiting consciousness $(b h \circ g \bar{a})$. Living entities in this consciousness do not go beyond the bodily identity of self (recognizing 
oneself as young, old, male, female and so on). In human form those who are ignorant about their true constitutional position, exercise their freedom to choose a position against their real nature. Ignoring their true position as eternal servants of Supreme Absolute these living entities can develop the moods of either active (exploitation - bhogā) or passive (renunciation - tyagga) hostilities towards the Supreme Absolute and proceed along the paths of karma or jñannalyoga respectively. The world of matter is dominated by the consciousness of exploitation (bhog $\bar{a}-$ 'freedom for the senses'/'endless sense gratification') and thus the activities of living entities are driven by 'laws of karma laws of action and reaction', which is an unnatural position for the living entities because spontaneous activity is the true nature of life. When the living entities are tired or feel distressed due to endless entanglement of karmic cycle, they try to find some short of relief/liberation from that suffering position by making the attempts to eliminate the consciousness itself - renunciation (tyāga - attempt to block sensual and mental temptations). However, renunciation (tyāga - withdrawal) cannot be a true remedy, as we all know retirement is hell. There are a few liberationists who think that renunciation (tya $\bar{a} g$ ) is the solution for overcoming the suffering condition from the reactionary plane of exploitation $(b h \circ g \bar{a})$ and thus they externally try to leave everything and advise others to do so. However, stopping all the activities (returning to zero) is undesirable and is against the real nature of the living entity. Arjuna also wanted to follow this path of renunciation - tyāga (he wanted to leave everything and wanted to go to forest) when he was in extremely distressed condition during the great Mahābhārata war. Bhagavān Sri Krishna in Śrimmad Bhagavad-gīta [96, 97] informs us through Arjuna that there is yet another much higher level of consciousness - dedicating consciousness (bhakti - 'freedom from the senses'/"process of engaging senses in the loving service of the center').

Aristotle presented a non-Cartesian view from which Descartes deviated by creating a mind body dualism [98]. In Aristotle's view matter and form are never separate. In hylomorphism, the real substantial being is the determinate being. Thus, human being is distinct from every other kind of being. Aristotle applied the concept of hylomorphism to living objects [99]. It implies that matter and form are inseparable. They are always united in the potential and actual form. The bodily structure of bacteria, fishes, plants, animals and human are distinct. Every species represents a distinct hylomorphic body-form. We will not be able to scientifically transpose one living form to another (say, a bacterium to a fish). However, some adaptability is there within the species (microevolution) and there is also development (ontogeny). Some constant alteration is going on restlessly and therefore species is a bounded, but pliable within the boundaries that do not cross the species line (here species indicates anatomically different living forms). Thus, in contrast to Darwinian gradualism, species are conserved in nature. Darwinian objective evolution theory of bodies using the laws of physics and chemistry cannot explain why species like bacterium, fish, frog, banyan tree, lion and so on appeared. On the other hand, the conception of Vedānta holds that different gross and subtle bodies (species) are original archetypes that accommodate different varieties of consciousness through which the transmigration of the soul (ätman) takes place on the basis of the subjective evolution of consciousness. For example, Viṣnu Purāna states:

\section{jala-jā nava-laksāṇi sthāvarā laksa-vimśati krmayo rudra-sańkhyakāh paksiṇām daśa-laksaṇam trimśal-laksāṇi paśavah catur-laksāṇi mānusāḥ}

Translation: There are 900,000 species living in the water. There are also 2,000,000 nonmoving living entities (sthāvara), such as trees and plants. There are also 1,100,000 species of insects and reptiles, and there are 1,000,000 species of birds. As far as quadrupeds are concerned, there are 3,000,000 varieties, and there are 400,000 human species.

According to Vedānta, species identification and classification are based on a cognitive paradigm, where the body is a biological illusion of the consciousness of the soul (ätman). The different species described in the above verse are representations of different varieties of consciousness which in turn are represented in different subtle bodies (süksma-deha). Therefore, in the material sphere the different species are actually different subtle bodies. The explanation that there are 400,000 types of human species or $1,000,000$ species of birds is actually representation of different subtle bodies. In Vedāntic view species classification is based on subtle body (süks ma-deha) and the gross body (sthūla-deha) is an expression of the subtle body (süks ma-deha). In other words, the development of gross body (sthüla-deha) is based on subtle body (sūks ma-deha).

The transmigration of the soul (atman) is described in Bhagavad-gìtā 8.6: yam' yam' vāpi smaran bhāvam' tyajanty ante kalevaram tam tam evaiti kaunteya sadā tad bhāva-bhāvitah - "The soul (ātman) obtains a body in next life based on the consciousness in which it left the previous body." According to Vedāntic philosophy animals and lower species of life do not have enough intelligence to understand these descriptions of ancient wisdom. However, a sober human being may easily understand his/her entanglement in the dangerous cycle of endless transmigration and thus inquire about true identity of self as the immortal soul under an expert spiritual guide.

Vedānta advocates this scientifically verifiable subjective evolution of consciousness, while the unscientific Darwinian objective evolution of bodies is only a misconceived perverted reflection of this subjective evolution of consciousness. Vedāntic philosophy agrees with Darwin's claim that, the world is evolving rather than remaining constant. The evolution theory itself is teleological because according to this theory the only internal goal of an organism is "survival". However, in Vedantic philosophy, spiritually ignorant and enlightened living entities address this internal goal very differently. According to Vedānta, consciousness is the inferential proof or symptom of existence of the soul 
(ätman) or the living entity, and the soul (ätman) possesses the qualities of sat, cit and ānanda. All life exhibits these same qualities. Every living organism wants to maintain its life forever (sat) and is willing to engage in the struggle for existence until it is forced by the laws of material nature to succumb to physical death of the body. The fact that life goes on generation after generation for thousands or millions of years is not something we would expect in chemical or physical material processes. It is sentient or conscious (cit) and seeks knowledge in the human form. And all life seeks fulfilment (ānanda) through nutrition, and various other forms according to the spiritual development of the various qualities of the soul (ätman) within the different bodies. All these different symptoms give evidence for the existence of the spiritual soul (ätman), for they are certainly not the qualities of matter.

Our body was in the state of a single cell zygote when it first came into existence and by miraculous embryological development it has acquired a child body. By several changes, it has acquired its present state and it will further change to acquire its future state. Therefore, our body is in a constant state of flux, like a river. The Vedāntic view of the principle of reincarnation (metempsychosis) can be found in its nascent form in the changing of our body, from the child body, to the youth body, to the old body. We can scientifically observe that our body is already changing several times in our lifetime itself, and in a similar manner at the time of death, the eternal soul (atman) will go to another body under certain conditions. As the body is under constant replenishment, Vedānta explains that bodily identity of self is illusory. Until they are forced by the laws of material nature to succumb to physical death of the body, throughout their entire life span, spiritually ignorant living entities try to focus their entire energy only towards the welfare of body and bodily gains. On the other hand, by overcoming the illusory bodily identity of self and realizing that they are part of an 'Organic Whole', spiritually enlightened living entities are always engaged in their true constitutional position (svarūpa) as eternal dedicating units of the Center - the àdi-purușa or primeval personal Absolute.

\section{Conclusions}

The theories of logical positivists, physicists and mathematicians are based on natural laws and therefore, those theories are generally strictly deterministic. It was proclaimed by the famous French mathematician and physicist Laplace, that it is possible to predict the future by gaining a complete knowledge of the current universe and all its processes [100]. However, successive scientific advancements confirmed the naivety of this strict deterministic view [101]. This refutation of strict determinism certainly encourages a completely different approach to the study of the reality. Especially biological systems, which display an "internal teleology", can only be addressed by a cognitive analysis. In biological systems also we observe regularities but it is highly questionable whether they can be addressed by the same natural laws of the physical sciences [102]. The main reason for the lesser importance of natural laws in biological theory formation is perhaps the greater role played in biological systems by sentience and cognition. An external gross application of Popper's method of falsification for theory testing on subtle cognitive nature of biological systems is untenable, because biology is a science of concepts and not laws. To overcome this wrong approach is the first, and perhaps the hardest, step towards developing a solid foundation for biology proper.

Like the man searching for his key under the lamppost, we currently focus our scientific studies about life almost completely on limited tools available in physical sciences, because our ability to study and control the matter (abiology) lies at the heart of modern day science. This unreasonable belief that the tools that are used in physical sciences are the only means to know the reality, certainly limits the 'knowability using science' to a very insignificant domain of entire reality. Life, which seems to involve much more complex subjects like mind, sentience, consciousness, and subjective experiences like love, affection, anger, happiness, motherhood and so on, is certainly beyond the comprehension of this limited domain that we have created for science. We should not bring science under such speculative limitations and to overcome this great lacuna modern science badly needs proper philosophical tools.

Knowledge received by sensual experiences always faces problems when the objects are too small (say, an electron) or too big (say, gigantic planets). Furthermore, a living entity existing in the plane of mundane consciousness has four defects. They are bhrama, pramāda, vipralips $\bar{a}$ and karaṇāpāț ava (Śrī Caitanya-caritāmr ta Ādi-līlā 2.86). Bhrama means that there is a tendency to make mistakes or arriving at false knowledge about something. For example, one may accept a piece of rope as a snake or may think an oyster shell as gold. The tendency of being inattentive and being illusioned is called pramāda. This leads to various kinds of misunderstandings. The propensity of living entities to cheat others is also a defect known as vipralipsa $\bar{a}$. Finally the imperfectness of senses is the defect that is known as karañapat ava. For example, a straight stick appears bent when it is partially dipped in transparent water. We experience mirage in a desert. We cannot hear sound outside the audible range. The eyes cannot see something that is very far or very near. If there is a disease like jaundice, then everything appears tinged by yellow color.

Therefore, without the help of sabda-brahma, or the revealed knowledge, the evidence collected by only direct sense perception and inference is always liable to be affected by the aforementioned four defects. But when these evidences are guided by śabda-brahma they can also become perfect. In other words, our senses must be engaged in the process of higher inquiry under the guidance of authorities who are well versed in the system of knowledge presented in Vedānta.

There are five epistemological levels in Vedānta [103]: 
(i) pratyakș $a$ : This is the knowledge acquired from faith in one's own direct sense perceptions. What we experience through our own senses is considered the first stage of knowledge and is the lowest form of knowledge.

(ii) parokșa: parokșa means others. As compared to pratyaks $a$ this is a higher form of knowledge. It is the knowledge from faith in other's sense perception. This knowledge is not gained directly from our own senses but is gathered from other's sense experience. For example we gather knowledge by having faith on the inventions and discoveries of scientists.

(iii) aparokșa: A kind of hazy knowledge coming from self, where the object of knowledge and subject become indistinguishable. This kind of experience is called aparoks $a$, which is indistinct. In this experience the subject and material object come together, and the material object vanishes in the subject. Sripad Madhvacharya has given the explanation of aparoks $a$ experience from the example of a deep and dreamless sleep. In the state of sound dreamless sleep the gross senses (taste, aroma, touch, sight and sound) are not active and even the mind (the impulse, which acts through these gross senses) remains dormant. However, on awakening from such a sleep, one still has the tangible recollection that he has had the experience of sleeping soundly and also that time had passed. Therefore, Sripad Madhvacharya argued in his dialectical system of philosophy called Śuddha-Dvaita-Vāda that there is a knowing ability in the self (which we intuit as ' $I$ ') that are distinct from the abilities coming from the five sensory organs as well as mind. This domain of knowledge that comes from self is called aparoks $a$. One must note here the distinction between Sripad Sankaracharya and Sripad Madhvacharya. According to Sripad Sankaracharya, although the soul (ätman) is there, it has no determinations and it is unknowable, indescribable and there are no distinctions there. Therefore, followers of Sripad Sankaracharya insist that a process of unaided dry meditation on a so called unknowable self is the only means for overcoming the material plane of existence. On the other hand, Sripad Madhvacharya has made it clear that there are a multitude of souls (ätmans) and that the ätman can know itself, as well as let itself be known by other souls (ātmans), because it can do so from the plane of self-knowing by its internal determinations, or aparoks a plane of experiencing. Therefore, monists have a wrong notion that soul (ätman) is indescribable, because, soul (ätman) does have determinate qualities and is thus describable.

(iv) adhoks aja: According to Sripad Ramanuja Acharya and other Vais ṇ ava Ācāryas there is a fourth stage beyond the plane of aparoks $a$ stage and that is called the adhoks aja or the transcendental plane. This system of knowledge is beyond the scope of the senses (both the gross as well as the subtle senses). Adhah means above and akș aja means eye or the knowing organ, and hence adhoks aja means that, which is coming from above the knowing organ of the self or soul (atman). It is the knowledge coming down from above the plane of self or from the supramental and super-subjective plane (known as Vaikuṇt ha) and it is transcendental knowledge. This superior knowledge can force down all our knowledge of the experience of this mundane world. Here the subject is underground and the object of knowledge in above the ground. It comes on its own accord to the level of our gross or subtle understanding. If it withdraws we are unable to have it and we become helpless in this. We cannot force our own entry into that plane. This kind of knowledge is not within our fists and it is the fourth plane of consciousness, it is grand, all powerful and all inspiring. Thus the Absolute is not within our control.

(v) aprākrta: This is the stage of continuous transcendental life in plane of love of Godhead. Here the controlling factors are mercy, pity and love. A king has no need to play with an ordinary boy in the street and yet love can make it possible. Therefore, the Absolute independent cognizant being can agree to play with even the most insignificant living entity due to the controlling power of love. This is the full-fledged theistic conception, which is only found in Goloka Vr ndāvana. Sri Chaitanya Mahaprabhu and his followers discussed this stage of experience, which is very similar to this mundane world, yet is not mundane. Vedic literature explains that the mundane world or 'illusory world' is a perverted reflection of the world of absolute.

At the present state of extreme perplexities modern science can be greatly benefited if it can try to systematically study the five epistemological levels explained in Vedānta.

\section{ACKNOWLEDGEMENTS}

The authors sincerely acknowledge the guidance and blessings of their Diksha and Siksha Gurudevs Srila Bhaktisvarupa Damodara Maharaja (Dr. T. D. Singh, Founding Director - Bhaktivedanta Institute) and Sripad Bhakti Madhava Puri Maharaja, Ph.D. (Serving Director, Bhakti Vedanta Institute: www.bviscs.org and Founder of Sri Chaitanya Saraswat Institute: www.scsiscs.org). Our Siksha Gurudev Sripad Bhakti Madhava Puri Maharaja, $\mathrm{Ph} . \mathrm{D}$. has been guiding us in these works for more than a decade. Sri Guru is the divine messenger of immortal hope and joy in this mortal and miserable world.

We also thank and acknowledge the help that we have received from all the well wishers and valuable friends: Bharath Cherukuri, Sri Ramachandra Medical College and Research Institute, Chennai, India; Sripad Sandeep Krishna Prabhu \& Damayanti Didi, Hyderabad, India; Sripad Brajagopal Prabhu, Vijayawad, India; Tupakula Krishna Geethika Yadav, Guntur, India; Dr. K. V. S. Kumar Choudary, NRI Medical College and General Hospital, Guntur, India; Naripeddi Srinivas Chowdary, BI Consultant, Pune, India; T. Indira Rani Yadav, National Tertiary Education Consortium (Ntec), Auckland, New Zealand; Anil Prasad Vemulapalli, USA; Ramya Narendra Reddy, B.E., Electronics, Bangalore, India; Dasharath Patel, Software Engineer, Ahmadabad, Gujarat, India; Chennunboina Rajesh Yadav, Bachelor of Veterinary Science, Sri Venkateswara 
Veterinary University, Tirupati, India.

\section{REFERENCES}

[1] Shanta, B.N., 2015, Life and consciousness - The Vedantic view., Communicative \& Integrative Biology, 8(5), e1085138; http://dx.doi.org/10.1080/19420889.2015.1085138

[2] Rose, S.P.R., 2012, Human agency in the neurocentric age., EMBO Rep., 6, 1001-1005; http://dx.doi.org/10.1038\%2Fsj. embor.7400566

[3] Abel, D.L., 2012, Is life unique?, Life (Basel), 2, 106-134; http://dx.doi.org/10.3390/life2010106

[4] Pennock, R.T., 1995, Moral Darwinism: Ethical evidence for the descent of man., Biology and Philosophy, 10, 287-307; http://dx.doi.org/10.1007/BF00852470

[5] Theise, N.D., Kafatos, M.C., 2013, Sentience everywhere: Complexity theory, panpsychism and the role of sentience in self-organization of the universe., J. Consciousness Exploration \& Research, 4, 378-390; http://jcer.com/index.p hp/jcj/article/view/291/330

[6] Ben-Jacob, E., Shapira, Y., Tauber, A.I., 2006, Seeking the foundations of cognition in bacteria: From Schrödinger's negative entropy to latent information., Physica A, 359, 495-524; http://dx.doi.org/10.1016/j.physa.2005.05.096

[7] Minton, A.P., 2006, How can biochemical reactions within cells differ from those in test tubes?, J. Cell Sci., 119, 2863-2869; http://dx.doi.org/10.1242/jcs.03063

[8] Mazzocchi, F. 2011, The limits of reductionism in biology: What alternatives?, E-LOGOS: Electronic J. Philosophy, 11, 1-19; http://nb.vse.cz/kfil/elogos/science/mazzocchi11.pdf

[9] Martin, A.C.R. et al., 1999, Protein folds and functions., Structure, 6, 875-884; http://dx.doi.org/10.1016/S0969-2126 (98)00089-6

[10] Van Regenmortel, M.H.V., 1999, Biosensors and the search for structure-activity correlations., J. Mol. Recogn., 12, 277-278; http://dx.doi.org/10.1002/(SICI)1099-1352(19990 9/10)12:5<277::AID-JMR466>3.0.CO;2-1

[11] Needleman, D., Brugues, J., 2014, Determining physical principles of subcellular organization., Dev Cell, 29, 135-138; http://dx.doi.org/10.1016/j.devcel.2014.04.018

[12] Todd, R.B., 1976, The four causes: Aristotle's exposition and the ancients., J. History of Ideas, 37, 319-322; http://dx.doi.org/10.2307/2708827

[13] Berger, R., 1998, Understanding science: Why causes are not enough., Philos. Sci., 65, 306-332; http://www.jstor.org/stabl e/188263?seq=1\#page_scan_tab_contents

[14] Waldrop, M.M., 1990, Goodbye to the warm little pond?, Science, 250, 1078-1080; http://dx.doi.org/10.1126/science. 11536475

[15] Kelley, D., Is it time to throw out 'primordial soup' theory? NPR, February 7, 2010. http://www.npr.org/templates/story/ story.php?storyId=123447937

[16] J.A. Shapiro, Evolution: A view from the 21st century. Upper
Saddle River, NJ: FT Press, 2011.

[17] S. Rose, What is wrong with reductionist explanations of behaviour?, The limits of reductionism in biology, G. Bock and J. Goode, Eds. Novartis Foundation Symposium, No. 213, Wiley, Chichester, UK: 176, 1998.

[18] P. Achinstein, The nature of explanation, Oxford University Press, New York: 385, 1983.

[19] Noonan, J.P., 2010, Neanderthal genomics and the evolution of modern humans., Genome Res., 20, 547-553; http://dx.doi.org/10.1101/gr.076000.108

[20] J. Diamond, The third chimpanzee: The evolution and future of the human animal, New York, HarperCollins: 1992.

[21] Varki A., Altheide, T.K., 2005, Comparing the human and chimpanzee genomes: Searching for needles in a haystack., Genome Res., 15, 1746-1758; http://dx.doi.org/10.1101/gr.3 737405

[22] Collard, M., Wood, B., 2000, How reliable are human phylogenetic hypotheses?, Proc. National Academy of Sciences, 97, 5003-5006; http://dx.doi.org/10.1073/pnas.97. 9.5003

[23] Sober, E., 2009, Did Darwin write the origin backwards?, Proc. National Academy of Sciences, 106, 10048-10055; http://dx.doi.org/10.1073/pnas.0901109106

[24] F. Darwin, The life and letters of Charles Darwin, 2, John Murray: 296, 1887.

[25] Wagner, G.P., Lynch, V.J., 2010, Evolutionary novelties., Current Biology, 20, R48-R52; http://dx.doi.org/10.1016/j.cu b.2009.11.010

[26] Gohau, G., 2010, Darwin the geologist: Between Lyell and von Buch., C. R. Biol., 333, 95-98; http://dx.doi.org/10.1016 /j.crvi.2009.11.008

[27] B.N. Shanta, 2014, The chronology of geological column: An incomplete tool to search georesources, Geo-Resources. K.L. Shrivastava, A. Kumar, P.K. Srivastav, H.P. Srivastava, Eds. Scientific Publishers, Jodhpur, India: 609-625, 2014; http://dx.doi.org/10.13140/RG.2.1.4409.4808

[28] Koonin, E.V., 2007, The biological big bang model for the major transitions in evolution., Biol Direct, 2:21; http://dx.doi.org/10.1186/1745-6150-2-21

[29] Kuhn, J.A., 2012, Dissecting Darwinism., Proc Bayl Univ Med Cent, 25, 41-47; http://www.ncbi.nlm.nih.gov/pmc/arti cles/PMC3246854

[30] National Research Council, Species definitions and the endangered species act, Species definitions and the endangered species act, Natl. Acad. Press, Washington, DC: 1995.

[31] Birky Jr., C.W., 2013, Species detection and identification in sexual organisms using population genetic theory and DNA sequences., PLoS One, 8, e52544; http://dx.doi.org/10.1371/ journal.pone.0052544

[32] E. Mayr, Animal species and evolution, Cambridge, MA, Harvard University Press: 1963.

[33] Wolf, J.B.W., Lindell, J., Backström, N., 2010, Speciation genetics: Current status and evolving approaches., Philos 
Trans R Soc Lond B Biol Sci., 365, 1717-1733; http://dx.doi.org/10.1098/rstb.2010.0023

[34] Jacob, F., Monod, J., 1961, Genetic regulatory mechanisms in the synthesis of proteins., J. Mol Biol., 3, 318-356; http://dx.doi.org/10.1016/S0022-2836(61)80072-7

[35] Mathematical challenges to the neo-Darwinian interpretation of evolution, P.S. Moorhead and M.M. Kaplan, Eds. Philadelphia, Wistar Institute Press: 1967.

[36] Crick, F., 1970, Central dogma of molecular biology., Nature, 227, 561-563; http://dx.doi.org/10.1038/227561a0

[37] Silva, S., Martins, Y., Matias, A., Blickstein, I., 2010, Why are monozygotic twins different?, J Perinat Med., 39, 195-202; http://dx.doi.org/10.1515/JPM.2010.140

[38] V.J. Stenger, 1999, The physics of 'alternative medicine'. Bioenergetic Fields, The scientific review of alternative medicine, 3 .

[39] R. Sheldrake, The presence of the past: Morphic resonance and the memory of nature, Park Street Press, 4th Edition: 86-87, 2012.

[40] Gotthelf, A. 1976, Aristotle's conception of final causality., Review of Metaphysics, 30, 226-254; http://www.jstor.org/st able/20126919?seq=1\#page_scan_tab_contents

[41] Krafft, F., 1982, Die Idee der Zweckmässigkeit in der Geschichte der Wissenschaften., Berichte zur Wissenschaftsgeschichte, 5, 1-152; http://dx.doi.org/10.1002/bewi.19820050102

[42] Lehner, B., 2007, Modelling genotype-phenotype relationships and human disease with genetic interaction networks., The J. Experimental Biology, 210, 1559-1566; http://dx.doi.org/10.1242/jeb.002311

[43] Godfrey-Smith, P., 2000, On the theoretical role of "genetic coding", Philosophy of Science, 67, 26-44; http://dx.doi.org/10.1086/392760

[44] Shapiro, J.A., 2009, Revisiting the central dogma in the 21st century., Natural Genetic Engineering and Natural Genome Editing: Ann. N.Y. Acad. Sci., 1178, 6-28; http://dx.doi.org/10.1111/j.1749-6632.2009.04990.x

[45] Hämmerling, J., 1963, Nucleo-cytoplasmic interactions in acetabularia and other cells., Ann Rev Plant Physiol, 14, 65-92;

http://dx.doi.org/10.1146/annurev.pp.14.060163.000433

[46] Chapman, C.J., Nugent, N.A., Schreiber, R.W., 1966, Nucleic acid synthesis in the chloroplasts of acetabularia mediterranea., Plant Physiol, 41, 589-592; http://dx.doi.org/10.1104/pp.41.4.589

[47] Shapiro, J.A., 2006, Genome informatics: The role of DNA in cellular computations., Biological Theory, 1, 288-301; http://dx.doi.org/10.1162/biot.2006.1.3.288

[48] Shapiro, J.A., 2007, Bacteria are small but not stupid: Cognition, natural genetic engineering and socio-bacteriology., Stud Hist Phil Biol \& Biomed Sci, 38, 807-819; http://dx.doi.org/10.1016/j.shpsc.2007.09.010

[49] Popescu, S., 2014, Nonlocality beyond quantum mechanics, Nature Physics, 10, 264-270; http://dx.doi.org/10.1038/nphy s2916
[50] Heisenberg, W., 1927, Über den anschaulichen Inhalt der quantentheoretischen Kinematik und Mechanik., Zeitschrift für Physik (in German), 43(3-4), 172-198; http://dx.doi.org/10.1007/BF01397280

[51] M. Srednicki, Quantum field theory, Cambridge University Press, New York: 2007.

[52] Hobson, A., 2013, There are no particles, there are only fields., American J. Physics, 81, 211; http://dx.doi.org/10.1119/1.47 89885

[53] Groeblacher, S., Paterek, T., Kaltenbaek, R., Brukner, C., Zukowski, M., Aspelmeyer, M., Zeilinger, A., 2007, An experimental test of non-local realism., Nature, 446, 871-875; http://dx.doi.org/10.1038/nature05677

[54] Jungerman, J.A., World in process: Creativity and interconnection in the new physics, Suny Press: 2000.

[55] E. Powell, Anton Zeilinger - Reality discover interview: Anton Zeilinger dangled from windows, teleported photons, and taught the Dalai Lama what started out as totally intellectual, impractical experiments could help pave the way for a revolution in computing: August 29, 2011; http://www.naiverealismandawakening.com/?page_id=1164

[56] Harnad, S., 1995, Why and how we are not zombies., J. Consciousness Studies, 1, 164-167.

[57] Chalmers, D., 1995, Facing up to the problem of consciousness., J. Consciousness Studies, 2, 200-219.

[58] Eckhorn, R., Bauer, R., Jordan, W., Brosch, M., Kruse, W., Munk, M., Reitbeock, H.J., 1988, Coherent oscillations: A mechanism for feature linking in the visual cortex? Multiple electrode and correlation analyses in the cat., Biological Cybernetics, 60, 121-130; http://dx.doi.org/10.1007/BF0020 2899

[59] F.C. Crick, The astonishing hypothesis, Charles Scribner's Sons, New York: 1994.

[60] Crick, F.C., Koch, C., 1990, Towards a neurobiological theory of consciousness., Seminars in the Neurosciences, 2, 263-275.

[61] P. Maguire, P. Moser, R. Maguire, V. Griffith, Is consciousness computable? Quantifying integrated information using algorithmic information theory. P. Bello, M. Guarini, M. McShane, B. Scassellati, Eds. Proc 36th Ann Conf Cogn Sci Soc., Cognitive Science Society, Austin, TX: 2014.

[62] G. Edelman, The remembered present: A biological theory of consciousness. New York, Basic Books: 1989.

[63] R. Jackendoff, Consciousness and the computational mind, Cambridge, MIT Press: 1987.

[64] Schmidt, M., Lipson, H., 2009, Distilling free-form natural laws from experimental data., Science, 324, 81-85; http://dx.doi.org/10.1126/science.1165893

[65] Hillar, C., Sommer, F.T., 2012, Comment on the article "Distilling free-form natural laws from experimental data., arXiv:1210.7273 [nlin.AO]; http://arxiv.org/abs/1210.7273

[66] T. Nagel, The view from nowhere, Oxford, Oxford University Press: 55, 1989. 
[67] R. Penrose, Shadows of the mind, Oxford, Oxford University Press: 1994.

[68] Hameroff, S.R., 1994, Quantum coherence in microtubules: A neural basis for emergent consciousness? J. Consciousness Studies (Imprint Academic), 1, 91-118.

[69] McGinn, C., 1989, Can we solve the mind-body problem? Mind, 98, 349-66; http://www.jstor.org/stable/2254848?seq= 1\#page_scan_tab_contents

[70] F. de Saussure, Course in general linguistics (trans. Roy Harris), London, Duckworth: ([1916] 1983).

[71] C.S. Peirce, Collected writings (8 Vols.)., C. Hartshorne, P. Weiss and A.W. Burks, Eds. Cambridge, MA, Harvard University Press: 58, 1931.

[72] R. Rosen, Life itself: A comprehensive inquiry into the nature, origin, and fabrication of life, New York, Columbia University Press: 1991.

[73] W.M. Elsasser, Biological theory on a holistic basis, Baltimore, Privately printed: 1982.

[74] T.A. Sebeok, Ecumenicalism in semiotics. A perfusion of signs. T.A. Sebeok, Eds. Bloomington, Indiana University Press: 180-206, 1977.

[75] Kull, K., 1998, On semiosis, umwelt, and semiosphere., Semiotica, 120(3/4), pp. 299-310.

[76] Tan, S.Y., 2006, Brown J. Rudolph Virchow (1821-1902): Pope of pathology., Singapore Med J, 47, 567-578.

[77] Kull, K., 2001, Jakob von Uexküll: An introduction., Semiotica, 134(1/4), 1-59.

[78] J. von Uexküll, Umwelt und Innenwelt der Tiere. Berlin, J. Springer: 1909.

[79] Hoffmeyer, J., 2008, The semiotic niche., J. Mediterranean Ecology, 9, 5-30

[80] Grinnell, J., 1917, The niche-relationships of the California Thrasher., The Auk, 34, 427-433; http://dx.doi.org/10.2307/4 072271

[81] T.W. Schoener, §I.1 Ecological niche. The Princeton guide to ecology. S.A. Levin, S.R. Carpenter, H.C.J. Godfray, A.P. Kinzig, M. Loreau, J.B. Losos, B. Walker, D.S. Wilcove, Eds. Princeton University Press: 3, 2009.

[82] C. Emmeche, Causal processes, semiosis, and consciousness. J. Seibt, Eds. Process Theories: Crossdisciplinary Studies in Dynamic Categories. Dordrecht: Kluwer: 313-336, 2004.

[83] Kant, I., 1790, Kritik der Urteilskraft. http://gutenberg.spiegel.de/buch/3507/85.

[84] Aristotle, On the Soul (Translated by J.A. Smith), Chicago, Encyclopaedia Brittanica: 1952.

[85] Hegel, G.W.F., 1830, The philosophy of spirit. http://www.marxists.org/reference/archive/hegel/works/sp/su introd.htm.

[86] S.B. Thakura, Jaiva dharma, Sri Chaitanya Bani Press,
Mayapur: 276-77, 2002.

[87] B.R. Sridhar, Surrender to Guru. Sri Guru and his grace, Sri Chaitanya Saraswat Math, Ananta Printing and Publishing, Soquel, California: 1999.

[88] Terewavas, A., 2009, What is plant behaviour?, Plant, Cell and Environment, 32, 606-616; http://dx.doi.org/10.1111/j.1 365-3040.2009.01929.x

[89] Weiss, D.J., Santos, L.R., 2006, Why primates? The importance of nonhuman primates for understanding human infancy., Infancy, 9(2), 127-140; http://dx.doi.org/10.1207/s1 5327078in0902 3

[90] Boissy, A., et. al., 2007, Assessment of positive emotions in animals to improve their welfare., Physiology and Behavior, 92, 375-397; http://dx.doi.org/10.1016/j.physbeh.2007.02.00 3

[91] van Marle, K, et. al., 2006, How capuchin monkeys (cebus apella) quantify objects and substances., J. Comparative Psychology, 120(4), 416-426; http://dx.doi.org/10.1037/0735 -7036.120.4.416

[92] Thorndike, E.L., 1898, Animal intelligence: An experimental study of associate processes in animals., Psychol Monogr, 2(Suppl No 4), 1-109.

[93] de Waal, F.B.M., 2011, What is an animal emotion?, Ann. N.Y. Acad. Sci., 1224, 191-206; http://dx.doi.org/10.1111/j.1 749-6632.2010.05912.x

[94] Moodley, K., Do animals have morals and show empathy?, Independent. http://www.independent.co.uk/news/world/doanimals-have-morals-and-show-empathy-9940632.html.

[95] B.R. Sridhar, The subjective evolution of consciousness, Sri Chaitanya Saraswat Math, Ananta Printing and Publishing, Caifornia: 1989.

[96] B.R. Sridhar, Śrīmad Bhagavad-gītā: The hidden treasure of the sweet Absolute, Sri Chaitanya Saraswat Math: 2006.

[97] A.C.B.S. Prabhupada, Bhagavad-gītā as it is, Bhaktivedanta Book Trust: 1972.

[98] P. Hoffman, Essays on Descartes, Oxford University Press: 107, 2009.

[99] Johnston, M., 2006, Hylomorphism, J. Philosophy, 103(12), 652 .

[100] E. Nagel, The structure of science: Problems in the logic of scientific explanation, New York, Harcourt, Brace and World: 1961.

[101] G. Shafer, A mathematical theory of evidence, Princeton, NJ, USA, Princeton University Press: 17, 1976.

[102] J. Beatty, The evolutionary contingency thesis. Concepts, theories and rationality in the biological sciences. G.S. Wolters and J. Lennox, Eds. Pittsburgh, University of Pittsburgh Press: 45-81, 1995.

[103] B.R. Sridhar, The golden volcano of divine love, Sri Chaitanya Saraswat Math, Ananta Printing, Soquel, California: 129-131, 1996. 